\title{
IMPACTS OF ROCK MINERALIZATION AND POOR SANITARY SYSTEM ON BOREHOLE WATERS QUALITY AND THE HEALTH IMPLICATIONS
}

\author{
Nwonumara Godwin Nkwuda*, Mmaduka Amarachi Theophine, Okechukwu Idumah Okogwu \\ Department of Appied Biology, Faculty of Science, Ebonyi State University, PMB 53, Abakaliki, Ebonyi State, Nigeria \\ *Corresponding Author Email: ngnkwuda@gmail.com
}

This is an open access article distributed under the Creative Commons Attribution License, which permits unrestricted use, distribution, and reproduction in any medium, provided the original work is properly cited.

\section{ARTICLE DETAILS}

\section{Article History:}

Received 27 November 2018 Accepted 27 December 2018 Available online 2 January 2019

\section{ABSTRACT}

\begin{abstract}
The quality of borehole waters in Abakaliki metropolis, Ebonyi State, Nigeria was assessed for six months. The study was designed to focus on the impacts of some mineral elements and poor sanitary system on the water quality. $\mathrm{pH}$, conductivity and TDS were measured in situ while Calcium ion, Magnesium ion, Lead concentration and total coliform count were determined in the laboratory using standard methods. The results showed that mean $\mathrm{pH}(6.20)$ was lowest at Aguogboriga in the wet period while mean conductivity $\left(805.00 \mu \mathrm{S} \mathrm{cm}^{-1}\right)$ and TDS $\left(402.00 \mathrm{mg} \mathrm{L}^{-1}\right)$ were highest at Kpirikpiri in the dry season. Highest mean concentrations of Calcium ion $\left(84.17 \mathrm{mg} \mathrm{L}^{-1}\right)$ and Magnesium ion (149.37 mg L-1) were recorded in the wet period at Amasiri street. Mean Lead concentration (0.35 $\mathrm{mg} \mathrm{L}^{-1}$ ) was highest at Brakenbury in the dry period and total coliform (24 CFU ml-1) at Amasiri street in the wet period. The study revealed that $\mathrm{pH}$, Calcium ion, Magnesium ion, Lead ( $\mathrm{Pb}$ ) level and total coliform count were above the WHO acceptable standard for drinking water at some of the study locations. The target cancer risk (TR) calculated for $\mathrm{Pb}$ showed the possibility that individual might develop cancer over time of exposure. So, proper survey should be carried out before siting boreholes to reduce point source pollution.
\end{abstract}

\section{KEYWORDS}

Abakaliki, borehole, health risk index, total coliform, water quality.

\section{INTRODUCTION}

On a global scale, groundwater represents the world's largest and most important source of fresh potable water [1]. Groundwater provides potable water to an estimated 1.5 billion people worldwide daily and has proved to be the most reliable resource for meeting rural water demand in the sub-Saharan Africa [2]. Due to inadequate supply of water from pipe borne water in developing and underdeveloped countries, there has been an increase in the drilling of boreholes to meet the water demand of the growing population especially among rural dwellers where boreholes serve as alternative to well, pond or stream water in the dry season.

Generally, groundwater quality varies from place to place and may depend on seasonal changes, soil types, rocks formation and the surfaces through which it moves. As groundwater flows through bedrocks and sediments, metals such as iron and manganese are dissolved and may later be found in high concentrations in the water, while calcium and magnesium may occur as salts [3]. In addition, human activities can alter the natural composition of groundwater through the disposal of untreated waste or injection of wastes directly into groundwater. Herbicides, pesticides and fertilizers applied to lawns and crops can accumulate and migrate to the water tables thus affecting both the physical, chemical and microbial quality of water. In rural Africa, the most common type of sanitation is the pit latrines while in cities the water closet is used. Lack of proper sewage system for collection and treatment of waste water from the water system could lead to microbial contamination of groundwater. Proximity of some boreholes to solid waste dumpsites and animal house could also be a major source of groundwater contamination. Microbial contamination of groundwater may cause disease symptoms such as diarrhoea, cramps, nausea [4].

Groundwater can also be contaminated by heavy metals from mineralization of bedrocks during weathering and leachates from mining activities. However, there is paucity of information on groundwater quality in developing countries and most people inadvertently consume a high amount of heavy metals. Ingestion of heavy metals such as Aluminium, Cadmium, Manganese and Lead can cause decrease in immune system, retardation in intrauterine development and psychosocial dysfunctions due to depletion of essential nutrients and increase in occurrence of upper gastrointestinal cancer $(15 ; 22)$. Vulnerability of humans to $\mathrm{Pb}$ toxicity decreases with age [5]. High concentration of $\mathrm{Pb}(<$ $10 \mu \mathrm{g} \mathrm{dL}^{-1}$ ) in blood can lead to high blood pressure and decrease in glomerular filtration rate at concentration $<20 \mu \mathrm{g} \mathrm{dL}^{-1}$ in adult while among children it can cause anaemia, neurological impairment, renal alterations, colic, and impaired metabolism of vitamin D [5].

Therefore, groundwater quality monitoring and testing is paramount both in the developed and developing world since the key to sustainable water resources is to ensure that the quality is suitable for their intended uses. It is on this basis that the quality of some borehole waters in Abakaliki metropolis was assessed to ascertain the acceptability for human use. This can provide useful information that will help groundwater users and managers adopt measures that will avert the risk of possible groundwater contamination. 


\section{METHODOLOGY: STUDY AREA}

The study was carried out within Abakaliki metropolis, the capital of Ebonyi State from July to December, 2016. Samples were collected from Democracy Estate, Aguogboriga (6 $\left.19^{\prime} 16^{\prime \prime} \mathrm{N}, 8^{\circ} 05^{\prime} 05^{\prime \prime E}\right)$, Igwe Ogbuofia street within Kprirkpiri (6 $\left.6^{\circ} 20^{\prime} 03^{\prime \prime} \mathrm{N}, 8^{\circ} 06^{\prime} 03^{\prime \prime} \mathrm{E}\right)$, Amasiri street by Onwe road ( $\left.6^{\circ} 18^{\prime} 47^{\prime \prime} \mathrm{N}, 8^{\circ} 06^{\prime} 12^{\prime \prime} \mathrm{E}\right)$, Pele oil by Onuebonyi Junction (6॰ $18^{\prime} 34^{\prime \prime} \mathrm{N}$, $\left.8^{\circ} 08^{\prime} 35^{\prime \prime E}\right)$, Hill top by Water works $\left(6^{\circ} 19^{\prime} 48^{\prime \prime} \mathrm{N}, 8^{\circ} 07^{\prime} 16^{\prime \prime} \mathrm{E}\right)$, Brakenbury street $\left(6^{\circ} 19^{\prime} 29^{\prime \prime} \mathrm{N}, 8^{\circ} 06^{\prime} 46^{\prime \prime} \mathrm{E}\right)$. These locations were randomly selected based on residential cluster in the capital city and the residents use mainly borehole water for household chores.

The study area lies within the Guinea savannah and experiences distinct rainy (May-October) and dry season (November-April). The bedrock of the area is mainly bedded shale with occasional sand, splintery metamorphosed mudstone; lenses of sandstone and sandy limestone that are highly jointed and fractured [6]. The sedimentary rock is folded and fractured, particularly in Abakaliki, and the fold axes and dominant rock fractures are oriented and this formation is associated with the Lead-zinc mineralization [6]. The aquifer in the study area is formed by weathered rocks, alluvium and fractured zones. This can enhance easy mineralization of groundwater resulting to higher concentrations of dissolved ions especially at high water table period.

\subsection{Sample Collection and Analysis}

Water samples were collected directly from boreholes at the selected locations using sterile containers. The samples were collected for six months which covered parts of the rainy season and dry season. Some physicochemical parameters including Total Dissolve solids, Conductivity and $\mathrm{pH}$ were measured at the point of sample collection using Hanna TDS, conductivity and $\mathrm{pH}$ meters, respectively. The concentrations of dissolved metal ions $\left(\mathrm{Ca}^{2+}, \mathrm{Mg}^{2+}, \mathrm{Pb}^{2+}\right)$ were determined in the laboratory within 24 hours using standard methods as described in [7]. Total coliform count was determined using membrane filter technique [8].

\subsection{Data analysis}

The mean and standard errors of the physicochemical variables and heavy metal concentrations as well as total coliform count were presented in a table.

Daily intake of metal (DIM), Health risk index (HRI) and Target cancer risk (TR): The daily intake of metal from water, health risk index and target cancer risk for adults and children were calculated using the following equations:

$$
\text { DIM }=\frac{\left(\mathrm{C}_{\text {metal }} \times \mathrm{C}_{\text {factor }} \times \mathrm{D}_{\text {water intake }}\right)}{\mathrm{BW}_{\text {average weight }}} \quad \text { [9] }
$$

Where $\mathrm{C}_{\text {metal }}$ is the heavy metal concentration in water $\left(\mathrm{mg} \mathrm{L}^{-1}\right)$

$\mathrm{C}_{\text {factor }}$ is the conversion factor $(0.085)$ for $\mathrm{Pb}$ according to [10].

$D_{\text {water intake is the daily intake of water and }}$
$B W_{\text {average weight }}$ is average body weight.

Average body weights of adult and children were taken to be $55.90 \mathrm{~kg}$ and $15.00 \mathrm{~kg}$, respectively according to [11,12].

$$
H R I=\frac{D I M}{R_{f} D}
$$

where DIM is the daily intake of metals and $\mathrm{R}_{\mathrm{f}} \mathrm{D}$ is the reference oral dose value for $\mathrm{Pb}$ which $0.004 \mathrm{mg}$ is $\mathrm{kg}^{-1}$ bw day ${ }^{-1}$ ) according to [13].

$$
\mathrm{TR}=\frac{\left(\mathrm{MC} \times \mathrm{IR} \times 10^{-3} \times \mathrm{CPS} \times \mathrm{EF} \times \mathrm{ED}\right)}{(\mathrm{BW} \times \mathrm{ATc})}
$$

where TR represents the target cancer risk; MC represents metal concentration in water sample in $\mathrm{mg} / \mathrm{L}$; IR is ingestion rate (g/day), CPS is carcinogenic potency slope ( $\mathrm{mg} / \mathrm{kg}$ bw per day); EF is exposure frequency; ED is exposure duration; BW is average body weight; ATc is average of the time the metal could be carcinogenic (day per year). The values for IR, CPS, $\mathrm{EF}, \mathrm{ED}$, and ATc for estimation of target cancer risk in water were 2.2 liter per day, $0.009 \mu \mathrm{g}$ per gram per day, 360 days per year, 30 years, 0.6 hour per day, respectively according to [15-17].

\section{RESULTS}

\subsection{Physicochemical and Total Coliform Count}

The mean values of the physicochemical and bacteriological properties of water samples from the selected locations during the study period are shown in Table 1. Mean pH (6.20) was least in the rainy season at Aguogboriga and highest (7.60) at Onuebonyi in dry season. Mean Conductivity $\left(805.00 \mu \mathrm{S} \mathrm{cm}^{-1}\right)$ and TDS $\left(402.00 \mathrm{mg} \mathrm{L}^{-1}\right)$ were highest at Kpirikpiri in the dry season. The highest mean concentrations of calcium (84.17 $\mathrm{mg} \mathrm{L}^{-1}$ ) and magnesium ions (149.37 $\left.\mathrm{mg} \mathrm{L}^{-1}\right)$ were recorded at Amasiri in the rainy season. Mean Lead concentration $\left(0.35 \mathrm{mg} \mathrm{L}^{-1}\right)$ was highest at Brakenbury in the dry season and total coliform count $\mathrm{CFU} / 100 \mathrm{ml}$ ) at Amasiri in the rainy season [13]. ANOVA result showed that conductivity, TDS, calcium ion, magnesium ion and total coliform count varied significantly between season and the study sites. Mean values of $\mathrm{pH}$, calcium ion, Lead $(\mathrm{Pb})$ level and total coliform count were above WHO acceptable standard for drinking water at some of the study locations.

\subsection{Daily intake of metal, Health risk index and Target cancer risk for adult and children}

The estimated values of the daily intake of $\mathrm{Pb}$, health risk index and target cancer risk for adult and children are shown in Tables 2 and 3 , respectively. The values of DIM, HRI and TR recorded were higher for children compared to those of adult. The highest DIM ( $\left.9.9 \times 10^{-5}\right)$, HRI $(2.5$ $\left.\mathrm{x} 10^{-2}\right)$ and TR ( $\left.8.3 \times 10^{-3}\right)$ were recorded for children in the dry season at Brakenbury. However, lower values of the parameters were recorded at

\begin{tabular}{|c|c|c|c|c|c|c|c|c|c|c|c|c|c|}
\hline \multirow[b]{2}{*}{ PARAMETERS } & \multicolumn{2}{|c|}{ Aguogboriga } & \multicolumn{2}{|l|}{ Amasiri } & \multicolumn{2}{|c|}{ Onuebonyi } & \multicolumn{2}{|l|}{ Hill top } & \multicolumn{2}{|c|}{ Breakenbury } & \multicolumn{2}{|c|}{ Kpirikpiri } & $\begin{array}{l}\text { WHO } \\
\text { Standard }\end{array}$ \\
\hline & $\begin{array}{l}\text { Rainy } \\
\text { season }\end{array}$ & $\begin{array}{l}\text { Dry } \\
\text { season }\end{array}$ & $\begin{array}{l}\text { Rainy } \\
\text { season }\end{array}$ & $\begin{array}{l}\text { Dry } \\
\text { season }\end{array}$ & $\begin{array}{l}\text { Rainy } \\
\text { season }\end{array}$ & $\begin{array}{l}\text { Dry } \\
\text { season }\end{array}$ & $\begin{array}{l}\text { Rainy } \\
\text { season }\end{array}$ & $\begin{array}{l}\text { Dry } \\
\text { season }\end{array}$ & $\begin{array}{l}\text { Rainy } \\
\text { season }\end{array}$ & $\begin{array}{l}\text { Dry } \\
\text { season }\end{array}$ & $\begin{array}{l}\text { Rainy } \\
\text { season }\end{array}$ & $\begin{array}{l}\text { Dry } \\
\text { season }\end{array}$ & \\
\hline $\mathrm{pH}$ & $\begin{array}{l}6.20^{*} \\
\pm 0.10\end{array}$ & $\begin{array}{l}6.60 \\
\pm 0.10\end{array}$ & $\begin{array}{l}6.60 \\
\pm 0.20\end{array}$ & $\begin{array}{l}7.10 \\
\pm 0.10\end{array}$ & $\begin{array}{l}6.90 \\
\pm 0.20\end{array}$ & $\begin{array}{l}7.60 \\
\pm 0.10\end{array}$ & $\begin{array}{l}6.90 \\
\pm 0.10\end{array}$ & $\begin{array}{l}7.30 \\
\pm 0.10\end{array}$ & $\begin{array}{l}7.10 \\
\pm 0.20\end{array}$ & $\begin{array}{l}7.60 \\
\pm 0.10\end{array}$ & $\begin{array}{l}6.50 \\
\pm 0.20\end{array}$ & $\begin{array}{l}7.00 \\
\pm 0.10\end{array}$ & $\begin{array}{l}6.50 \\
8.00\end{array}$ \\
\hline $\begin{array}{l}\text { Conductivity } \\
\left(\mu \mathrm{S} \mathrm{cm}^{-1}\right)\end{array}$ & $\begin{array}{l}175.00 \\
\pm 0.20\end{array}$ & $\begin{array}{l}200.00 \\
\pm 0.70\end{array}$ & $\begin{array}{l}772.00 \\
\pm 0.30\end{array}$ & $\begin{array}{l}785.00 \\
\pm 0.90\end{array}$ & $\begin{array}{l}375.00 \\
\pm 0.50\end{array}$ & $\begin{array}{l}416.00 \\
\pm 0.50\end{array}$ & $\begin{array}{l}736.00 \\
\pm 0.70\end{array}$ & $\begin{array}{l}798.00 \\
\pm 0.10\end{array}$ & $\begin{array}{l}486.00 \\
\pm 0.40\end{array}$ & $\begin{array}{l}498.00 \\
\pm 0.20\end{array}$ & $\begin{array}{l}650.00 \\
\pm 0.20\end{array}$ & $\begin{array}{l}805.00 \\
\pm 0.70\end{array}$ & \\
\hline
\end{tabular}
Onuebonyi and Kpirikpiri for adults in the rainy season.

Table 1: Mean and standard errors of some Physicochemical variables and Total coliform count of the Borehole samples. 
Earth Sciences Pakistan (ESP) 3 (1) (2019) 10-13

\begin{tabular}{|c|c|c|c|c|c|c|c|c|c|c|c|c|c|}
\hline TDS $\left(\mathrm{mg} \mathrm{L}^{-1}\right)$ & $\begin{array}{l}88.00 \\
\pm 0.30\end{array}$ & $\begin{array}{l}100.00 \\
\pm 0.30\end{array}$ & $\begin{array}{l}342.00 \\
\pm 0.40\end{array}$ & $\begin{array}{l}386.00 \\
\pm 0.40\end{array}$ & $\begin{array}{l}182.00 \\
\pm 0.10\end{array}$ & $\begin{array}{l}209.00 \\
\pm 0.60\end{array}$ & $\begin{array}{l}364.0 \\
\pm 0.60\end{array}$ & $\begin{array}{l}395.00 \\
\pm 0.10\end{array}$ & $\begin{array}{l}242.00 \\
\pm 0.20\end{array}$ & $\begin{array}{l}248.00 \\
\pm 0.20\end{array}$ & $\begin{array}{l}321.00 \\
\pm 0.10\end{array}$ & $\begin{array}{l}402.00 \\
\pm 0.30\end{array}$ & 500.00 \\
\hline $\begin{array}{l}\text { Calcium (mg L- } \\
\text { 1) }\end{array}$ & $\begin{array}{l}22.04 \\
\pm 2.04\end{array}$ & $\begin{array}{l}17.04 \\
\pm 3.01\end{array}$ & $\begin{array}{l}84.17^{*} \\
\pm 2.00\end{array}$ & $\begin{array}{l}83.17^{*} \\
\pm 5.01\end{array}$ & $\begin{array}{l}31.06 \\
\pm 1.00\end{array}$ & $\begin{array}{l}13.03 \\
\pm 1.01\end{array}$ & $\begin{array}{l}21.04 \\
\pm 7.01\end{array}$ & $\begin{array}{l}47.10 \\
\pm 3.01\end{array}$ & $\begin{array}{l}54.11 \\
\pm 2.01\end{array}$ & $\begin{array}{l}57.63 \\
\pm 14.52\end{array}$ & $\begin{array}{l}40.08 \\
\pm 4.01\end{array}$ & $\begin{array}{l}53.12 \\
\pm 3.01\end{array}$ & 75.00 \\
\hline $\begin{array}{l}\text { Magnesium } \\
\left(\mathrm{mg} \mathrm{L}^{-1}\right)\end{array}$ & $\begin{array}{l}41.72^{*} \\
\pm 4.41\end{array}$ & $\begin{array}{l}19.46 \\
\pm 8.52\end{array}$ & $\begin{array}{l}149.37^{*} \\
\pm 4.20\end{array}$ & $\begin{array}{l}77.83^{*} \\
\pm 2.44\end{array}$ & $\begin{array}{l}50.46^{*} \\
\pm 3.08\end{array}$ & $\begin{array}{l}10.95 \\
\pm 1.22\end{array}$ & $\begin{array}{l}40.37 * \\
\pm 12.17\end{array}$ & $\begin{array}{l}26.98 \\
\pm 0.23\end{array}$ & $\begin{array}{l}77.38^{*} \\
\pm 3.56\end{array}$ & $\begin{array}{l}42.56^{*} \\
\pm 0.00\end{array}$ & $\begin{array}{l}55.85^{*} \\
\pm 1.78\end{array}$ & $\begin{array}{l}48.64^{*} \\
\pm 1.22\end{array}$ & 30.00 \\
\hline Lead (mg L-1) & $\begin{array}{l}0.03^{*} \\
\pm 0.01\end{array}$ & $\begin{array}{l}0.02^{*} \\
\pm 0.00\end{array}$ & $\begin{array}{l}0.05^{*} \\
\pm 0.00\end{array}$ & $\begin{array}{l}0.04^{*} \\
\pm 0.00\end{array}$ & $\begin{array}{l}0.01 \\
\pm 0.00\end{array}$ & $\begin{array}{l}0.05^{*} \\
\pm 0.00\end{array}$ & $\begin{array}{l}0.03^{*} \\
\pm 0.00\end{array}$ & $\begin{array}{l}0.04^{*} \\
\pm 0.00\end{array}$ & $\begin{array}{l}0.02^{*} \\
\pm 0.00\end{array}$ & $\begin{array}{l}0.35^{*} \\
\pm 0.02\end{array}$ & $\begin{array}{l}0.01 \\
\pm 0.00\end{array}$ & $\begin{array}{l}0.04^{*} \\
\pm 0.00\end{array}$ & 0.01 \\
\hline $\begin{array}{l}\text { Total Coliform } \\
\text { Count } \\
\text { (CFU/100ml) }\end{array}$ & $6.00 *$ & 0.00 & $24.00^{*}$ & 0.00 & $9.00^{*}$ & $2.00^{*}$ & $10.00^{*}$ & $2.00^{*}$ & $18.00^{*}$ & 0.00 & $12.00^{*}$ & 0.00 & $\begin{array}{l}0.00 \\
\mathrm{CFU} / 100 \\
\mathrm{ml}\end{array}$ \\
\hline
\end{tabular}

NB: Values with asterisks as superscript are above WHO standard for drinking water.

Table 2: Daily intake of metal (DIM) Pb for Adult, Health risk index (HRI) and Target cancer risk (TR)

\begin{tabular}{|c|c|c|c|c|c|c|c|c|c|c|c|c|}
\hline \multirow{3}{*}{$\begin{array}{l}\text { Sampled } \\
\text { Locations } \\
\text { Season } \\
\mathrm{Pb}\left(\mathrm{mg} \mathrm{L}^{-1}\right)\end{array}$} & \multicolumn{2}{|c|}{ Aguogboriga } & \multicolumn{2}{|c|}{ Amasiri } & \multicolumn{2}{|c|}{ Onuebonyi } & \multicolumn{2}{|c|}{ Hilltop } & \multicolumn{2}{|c|}{ Brakenbury } & \multicolumn{2}{|c|}{ Kpirikpiri } \\
\hline & Rainy & Dry & Rainy & Dry & Rainy & Dry & Rainy & Dry & Rainy & Dry & Rainy & Dry \\
\hline & 0.03 & 0.02 & 0.05 & 0.04 & 0.01 & 0.05 & 0.03 & 0.04 & 0.02 & 0.35 & 0.01 & 0.04 \\
\hline DIM & $2.3 \times 10^{-6}$ & $1.5 \times 10^{-6}$ & $3.8 \times 10^{-6}$ & $3.0 \times 10^{-6}$ & $7.6 \times 10^{-7}$ & $3.8 \times 10^{-6}$ & $2.3 \times 10^{-6}$ & $3.0 \times 10^{-6}$ & $1.5 \times 10^{-6}$ & $2.7 \times 10^{-5}$ & $7.6 \times 10^{-7}$ & $3.0 \times 10^{-6}$ \\
\hline HRI & $5.7 \times 10^{-4}$ & $3.8 \times 10^{-4}$ & $9.5 \times 10^{-4}$ & $7.6 \times 10^{-4}$ & $1.9 \times 10^{-4}$ & $9.5 \times 10^{-4}$ & $5.7 \times 10^{-4}$ & $7.6 \times 10^{-4}$ & $3.8 \times 10^{-4}$ & $6.7 \times 10^{-3}$ & $1.9 \times 10^{-4}$ & $7.6 \times 10^{-4}$ \\
\hline TR & $9.1 \times 10^{-4}$ & $1.3 \times 10^{-4}$ & $3.2 \times 10^{-4}$ & $2.6 \times 10^{-4}$ & $6.4 \times 10^{-5}$ & $3.2 \times 10^{-4}$ & $1.9 \times 10^{-4}$ & $2.6 \times 10^{-4}$ & $1.3 \times 10^{-4}$ & $2.2 \times 10^{-3}$ & $6.4 \times 10^{-5}$ & $2.6 \times 10^{-4}$ \\
\hline
\end{tabular}

\section{DISCUSSION}

\subsection{Physico-chemical Variables and Total coliform Count}

The $\mathrm{pH}$ of water samples from the selected locations were found to be more acidic in the rainy season compared to dry season except at Brakenbury where $\mathrm{pH}$ above neutral point was recorded in the rainy season. Lower $\mathrm{pH}$ recorded in most of the sampled locations in the rainy season could be due to increased carbonic acid level arising from microbial decomposition of sewage, which may have leaked into groundwater as water table increased [18]. Poor sanitary conditions in most developing cities lead to the leakage of faecal material and other organic waste from sewer system into groundwater in the wet season thereby causing direct contamination and the release more carbondioxide into the water, consequently reducing the $\mathrm{pH}$ level. According to a study, high groundwater levels, which flow faster in high permeable surface layer through a short distance in the wet season, can cause low $\mathrm{pH}$ due to higher organic content in the soil surface layer [19]. This agreed with the report of who stated that acidity in groundwater could be due to the presence of organic acid in the soil [20]. Extremely low groundwater in the dry period can also cause oxidation of sulphides, which increases the sulphate content in groundwater thereby increasing the acidity when water table rises.

Higher conductivity and TDS values recorded in the dry season could be due to increase in concentrations of dissolved ions from bedrocks due to lower water level. Some researchers have reported higher conductivity and TDS in the dry season although in surface water, which was attributed to high rate of evaporation that reduce water level $[21,22]$. Hence, higher conductivity recorded in the dry season in this study might be due to lower water level with a resultant increase in the concentrations of dissolved ions at that period.

The values recorded for calcium and magnesium ions at all the sampled locations in the wet and dry season except Onuebonyi in the dry season indicated that the water is hard. The characteristic sandy limestone, which among other types of formation makes up the bedrock of Abakaliki area could be responsible for the high calcium - magnesium ion level recorded during the study [6]. Acidification can result to long term increase in calcium and magnesium ions [19].

The lead levels for the sampled locations were above WHO limit for drinking water except at Onuebonyi and Kpirikpiri in the rainy season. The folded and fractured sedimentary rock in Abakaliki fold axes is associated with Lead - zinc mineralization according to [6]. This could be responsible for the high level of Lead recorded in the water samples. The presence of coliform bacteria recorded in most of the samples could be due to contamination by decayed organic matter, which might include sewage, leachates from sewer or septic system. Faecal contamination of groundwater as water has been reported to increase as water tables increases [8]. World Health Organization standard (WHO) for faecal coliform in drinking water is zero per $100 \mathrm{ml}$. Coliform bacteria in water samples do not cause disease, it is a fact that they are not normally found in groundwater [23]. However, its presence in groundwater samples is an indication that other pathogenic bacteria, viruses and protozoa may be present in the water.

\subsection{Daily intake of metal, Health risk index and Target cancer risk for adult and children}

The DIM recorded in this study were below the WHO tolerable daily intake of $\mathrm{Pb}$ of $0.001 \mathrm{mg} \mathrm{kg}-1 \mathrm{bw}$ per day [24]. At $0.004 \mathrm{mg} \mathrm{kg}-1 \mathrm{bw}$ per day, reported that the net accumulation of $\mathrm{Pb}$ in human is considered highly unlikely [25]. The HRI values indicate that the intake of water from the sampled locations may not pose health risk to individuals. However, the TR values at Amasiri in the rainy season, Onuebonyi and Brakenbury in the dry season indicate that the possibility of individuals developing cancer by continuous intake of water from these sources over a lifetime is high [26-28].

\section{CONCLUSION}

The importance of water to man cannot be underestimated; therefore, its quality for the maintenance of healthy living should not be compromised. Borehole water is one of the major sources of water for domestic and industrial uses in most cities in developing countries due to inadequate supply of pipe borne water. Its safety for human use is not guaranteed due to contamination from rock mineralization, domestic sewage and agricultural run-offs, hence the need for its regular assessment.

The assessment of borehole water within Abakaliki metropolis revealed that some of the samples had low $\mathrm{pH}$, high dissolved ions, were hard with high total coliform count and the Pb level above the WHO permissible limit. Although the daily intake of metal was at the safe level, the target 
cancer risk indicated the chance of individuals developing cancer on lifetime exposure. Therefore, preliminary treatment like boiling to reduce the hardness and eliminate the coliform bacteria especially at high water level period is advised to enhance water quality.

\section{ACKNOWLEDGEMENT}

We wish to acknowledge technical staff of Applied Biology laboratory for providing some of the materials that was used in carrying out the study.

\section{REFERENCES}

[1] Jain, C.K., Bandyopadhyay, A., Bhadra, A. 2010. Assessment of groundwater quality for drinking water purposes, District Nainital, Uttarakhand, India. Environmental Monitoring Assessment, 166, 663-676.

[2] Govindarajan, M., Senthilnathan, T. 2014. Groundwater quality and its health impact analysis in an industrial area. International Journal of Current and Microbiology Applied Sciences, 3, 1028 - 1034.

[3] Bello, O.O., Osho, A., Bankole, S.A., Bello, T.K. 2013. Bacteriological and physicochemical analyses of borehole and well water sources in IjebuOde, Southwestern Nigeria. International Journal of Pharmacology Biological Science, 8 (30), 18-25.

[4] FDEP. 2014. Health Effects and Standards for Microbiological contaminants. 2600 Blair stone Road M. S. 3500 Tallahassee, Florida.

[5] ATSDR. 2007. U.S. Department of Health and Human Services Public Health Service Agency for Toxic Substances and Disease Registry. www.atsdr.cdc.gov

[6] Umeji, A.C. 2000. Evolution of the Abakaliki and the Anambra Basins, Southeastern Nigeria. A report submitted to the Shell Petroleum Development Company Nigeria Limited, 155pp.

[7] AOAC. 1990. Official methods of Analysis. 15th edition, Association of Analytical chemists, USA.

[8] Bartram, J., Pedley, S. 1996. Microbiological Analyses, In: Water Quality Monitoring - A Practical Guide to the Design and Implementation of Freshwater Quality Studies and Monitoring Programmes. Bartram J. and Ballance R. (Eds). UNEP/WHO, 1 - 27

[9] Obiora, S.C., Chukwu, A., Davies, T.C. 2016. Heavy metals and health risk assessment of arable soils and food crops around $\mathrm{Pb}-\mathrm{Zn}$ mining localities in Enyigba, southeastern Nigeria. Journal of African Earth Sciences, 116, $182-189$

[10] Rattan, R.K., Datta, S.P., Chhonkar, P.K., Suribabu, K., Singh, A.K. 2005. Long-term impact of irrigation with waste water effluents on heavy metal content in soils, crops and groundwater-a case study. Agricultural Ecosystem Environment, 109, 310-322.

[11] Ge, K.Y. 1992. The Status of Nutrient and Meal of Chinese in the 1990s. Beijing People's Hygiene Press, pp. 414-434.

[12] WQHC. 2017. Water Quality and Health Council Publication.

[13] USEPA. 2006. United States, Environmental Protection Agency, Integrated Risk Information System. http://www.epa.gov/iris/substS.2017.
[14] Koki, I.B., Bayero, A.S., Umar, A., Yusuf, S. 2015. Health risk assessment of heavy metals in water, air, soil and fish. African Journal of Pure and Applied Chemistry, 9 (11), $204-210$

[15] Liang, F., Yang, S.G., Sun, C. 2011. Primary Health Risk analysis of metals in surface water of Taihu Lake China. Bulletin of Environmental Contamination Toxicology, 87 (4), 404 - 414.

[16] Liu, C.W., Liang, C.P., Lin, K.H., Jang, C.S., Wang, S.W., Huang, Y.K., Hsueh, Y.M. 2007. Bioaccumulation of arsenic compounds in aqua cultural clams (Meretrix lusoria) and assessment of potential carcinogenic risks to human health by ingestion, Chemosphere, 69, 128-134.

[17] Wu, B., Zhao, D.Y., Jia, H.Y., Zhang, Y., Zhang, X.X., Cheng, S.P. 2009. Preliminary Risk Assessment of trace metal pollution in surface water from Yagtze River in Nanjing Section, China. Bulletin of Environmental Contamination Toxicology, 82 (4), 405 - 416.

[18] FEM. 2013. $\mathrm{pH}$ of Water. Fondest Environmental, Inc.http://www.fondriest.com/environmentalmeasurements/parameters/water-quality/ph/

[19] Gert, K. 1994. Acidification effects on groundwater - prognosis of the risks for the future. Future Groundwater Resources at Risk. Proceedings of the Helsinki Conference, June 1994). IAHS Publications.

[20] Chapman, D. 1996. Water Quality Assessments: A Guide to the Use of Biota, Sediments and Water in Environmental Monitoring. Second Edition, Chapman and Hall Ltd., London, 651pp.

[21] Atobatele, E.O., Olutona, G.O. 2013. Spatio-seasonal physicochemistry of Aiba stream, Iwo, Nigeria. African Journal of Biotechnology, 12 (14), 1630-1635.

[22] Chikere, B.O., Okpokwasili, G.C. 2002. Seasonal dynamics of the organic pollution in a Niger Delta river receiving petrochemical effluents. Tropical Freshwater Biology, 11, 11-22.

[23] Wang, X., Sato, T., Xing, B., Tao, S. 2005. Health risks of heavy metals to the general public in Tianjin, China via consumption of vegetables and fish. Science of the Total Environment, 350, 28 - 37.

[24] WHO. 2011. Guidelines for Drinking - water Quality. Fourth Edition. Publications of the World Health Organization. 564 pp.

[25] Baars, A.J., Theelen, R.M.C., Janssen, P.J.C.M., Hesse, J.M., van Apeldoom, M.E., Meijerkink, M.C.M., Verdan, L., Zeilmaker, M.J. 2001. Reevaluation of human toxicological maximum permissible risk level. RIVM report, National Institute of Public Health and the Environment, 297pp.

[26] Ikeda, M., Zhang, Z.W., Shimbo, S.,Watanabe, T., Nakatsuka, H., Moon, C.S., Matsuda, I. N., Higashikawa, K. 2000. Urban population exposure to lead and cadmium in east and south-east Asia. Science of the Total Environment, 249, 373 - 384.

[27] Iyengar, V., Nair, P. 2000. Global outlook on nutrition and the environment: meeting the challenges of the next millenium. Science of the Total Environment, 249, 331 - 346.

[28] Turkdogan, M.K., Fevzi, K., Kazim, K., Ilyas, T., Ismail, U. 2003. Heavy metals in soil, vegetables and fruits in the endemicupper gastrointestinal cancer region of Turkey. Environmental Toxicology and Pharmacology, 13, 175- 179. 